\title{
Invertebrate borings from the Eocene of Seven Rivers, parish of St. James, western Jamaica
}

\author{
Stephen K. Donovan ${ }^{1,2} \cdot$ Roger W. Portell ${ }^{3}$
}

Received: 15 February 2019/Accepted: 5 March 2019/Published online: 21 March 2019

(C) Akademie der Naturwissenschaften Schweiz (SCNAT) 2019

\begin{abstract}
The fossil biota of the Eocene Yellow Limestone Group of Jamaica is diverse in vertebrates and, particularly, invertebrates. However, its invertebrate trace fossils remain understudied. Herein, we document the borings of the Seven Rivers vertebrate site in western Jamaica. This is in the Litchfield Formation, high in the Lutetian (about mid-Middle Eocene). The suite of borings identified from this site comprises Apectoichnus longissimus (Kelly and Bromley); Entobia isp.; Oichnus simplex Bromley; and Oichnus paraboloides Bromley. Substrates infested by Entobia isp. include both molluscs and sirenian ribs. Oichnus ispp. occur only in bivalves and are mainly non-penetrative, which may be a taphonomic artifact. Tubes of the common A. longissimus are preserved free from any woody substrates, which have presumably rotted away; however, one specimen has a dark, carbonaceous external film and others have carbonized wood inclusions. The occurrence of A. longissimus in the Jamaican rock record coincides with periods of sub-aerial exposure.
\end{abstract}

Keywords Litchfield Formation · Trace fossils · Systematics · Entobia · Gastrochaenolites · Apectoichnus

\section{Introduction}

The Yellow Limestone Group of Jamaica has yielded a diverse biota including numerous micro- and macrofossil groups (see, for example, many of the papers in Wright and Robinson 1993). However, the ichnological diversity of this suite of formations awaits elucidation. Hitherto, trace fossils have commonly received, at best, only passing mention in papers on other aspects of the Yellow Limestone Group (see, for example, Donovan et al. 1990, fig. 2) with rare exceptions (Donovan and Blissett 1998). Indeed, and perhaps unexpectedly, despite the fact that Yellow Limestone Group is a popular target for experts on many fossil groups, the Paleogene ichnology of Jamaica is best

Editorial Handling: D. Marty.

Stephen K. Donovan

Steve.Donovan@naturalis.nl

1 Taxonomy and Systematics Group, Naturalis Biodiversity Center, Postbus 9517, 2300 RA Leiden, The Netherlands

2 Department of Earth Sciences, University of New Brunswick, Fredericton, NB E3B 5A3, Canada

3 Florida Museum of Natural History, University of Florida, Gainesville, FL 32611, USA known from two less 'collector-friendly' units: the Paleocene-Lower Eocene Richmond Formation (Pickerill and Donovan 1991; Pickerill et al. 1992, 1993; Pickerill and Mitchell 1999; Donovan et al. 2005, 2015); and the Eocene formations of the White Limestone Group (Blissett and Pickerill 2003, 2004, 2007; Donovan et al. 2015). Neither of these units is renowned for the ease with which their macrobiota can be found and collected (note the comments of Donovan 2004, p. 3), unlike, for example, the subject of the present paper, the Litchfield Formation of the Yellow Limestone Group (Mitchell in press).

We submit that the paucity of systematic ichnological studies of the Yellow Limestone Group of Jamaica is an oversight rather than a true reflection of its diversity of trace fossils (Donovan et al. 2015, p. 380). The present paper is the first contribution of what we hope will become at least a healthy trickle of papers on this subject. Herein, we describe the borings of the Seven Rivers vertebrate site in the parish of St. James, western Jamaica, which form part of the collections of the Florida Museum of Natural History, University of Florida, Gainesville (UF), and the Department of Paleobiology, National Museum of Natural History, Smithsonian Institution, Washington DC (USNM). We recognize that this assemblage is incomplete, consisting only of invertebrate borings on shells and vertebrate 
bones, and specimens released from decomposed xylic substrates. The measured section of Mitchell (in press, fig. 3) demonstrates that these were associated with burrows made by invertebrates, namely Thalassinoides isp. and Ophiomorpha isp., and vertebrate trace fossils (crocodile coprolites).

\section{Locality and horizon}

The Seven Rivers site in the parish of St James, western Jamaica, is the most important vertebrate site in the Paleogene of Jamaica (Domning et al. 1997; Domning 2001; Portell et al. 2001; Donovan et al. 2007). It is situated at and around [NGR 5285 8810]; see the Jamaica metric edition 1:50,000 sheet \#6, 'The Cockpit Country'. Mitchell (in press) provides GPS co-ordinates. The site itself is a man-made drainage ditch.

The site was discovered by the junior author in the early 1990s. At this time, it was shown as Cretaceous (Maastrichtian) on the provisional geological sheet (Bateson undated), but the discovery of sea cow ribs and diagnostic invertebrates demonstrated that it was undoubtedly within the outcrop of the Eocene Yellow Limestone Group. Remapping by Mitchell (in press, figs. 2-4) has shown conclusively that the Seven Rivers site is within the Litchfield Formation, Yellow Limestone Group. This is near the top of the Lutetian (about mid-Middle Eocene) and coeval with the other important vertebrate site of the Yellow Limestone Group, the Dump Limestone lenticle (Berg 1969; Robinson 1969; Donovan et al. 1990).

\section{Systematic ichnology}

Remarks Some of the images used herein first appeared in Donovan et al. (2015, fig. 5) and were referred to derivation from "... Donovan and Portell, in press ..." in the caption (p. 368 therein). This paper has been withdrawn from Domning and Portell (in press), revised and is now published herein.

\section{Ichnogenus Entobia Bronn 1837}

Type ichnospecies Entobia cretacea Portlock 1843, p. 360, by the subsequent designation of Häntzschel (1962, p. W230), from the Campanian(?) of Magilligan, Co. Londonderry, Northern Ireland, UK (Bromley 1970, p. 78).

Diagnosis (Slightly modified after Bromley and D'Alessandro 1984, p. 238.) "Boring in carbonate or phosphatic substrates comprising a single chamber or networks or boxworks of galleries connected to the surface by several or numerous apertures. Morphology changes markedly with ontogeny. The galleries show progressive increase in diameter during growth; in some forms, inflation at more or less regular distances produces a system of closely interconnected chambers; in other forms, chamber development is restricted to only a brief ontogenetic stage; in still other forms, no cameration is developed. The surface of the boring bears a cuspate microsculpture that may be lost in gerontic specimens. Fine apophyses arise from all or most surfaces of the system."

Remarks Unlike the body fossils of sponges, which remain rare throughout the fossil record of Jamaica and the Caribbean (Blissett et al. 2007; Donovan and Stemann 2007), the borings of the family Clionaidae (Bromley 2004, p. 459) - that is, Entobia ispp.-are locally common and have been found at many horizons in the Jamaican Cenozoic (see, for example, Donovan and Blissett 1998; Donovan et al. 2015). The occurrence of common Entobia in sirenian ribs at Seven Rivers (Fig. 1a, b) has necessitated a minor revision of the original diagnosis to include such calcium carbonate/phosphatic substrates. However, it is debatable if substrate composition is a valid ichnotaxobase (Donovan and Pickerill 2002; Donovan 2018; Donovan and Ewin 2018; contra Höpner and Bertling 2017).

\section{Entobia isp.}

Figure 1a-c, g

2015 Entobia isp.; Donovan et al., p. 370, Table 2, Fig. 5a-c, e.

Material Four infested bivalves, UF 166613 and 166940 (both in Carolia jamaicensis Dall, 1898, valves; Fig. 1c), and UF 166635 and 166881 (both infesting ostreid valves). Two specimens, UF 166937 (Fig. 1g) and 166938, are preserved as infills of single chambers. Bored sirenian ribs, USNM 546140 to 546142 (Fig. 1a, b).

Horizons Specimens variously from beds 2 (UF 166940), 8 (UF 166613) and 18, particularly 18-C (UF 166881, 166937, 166938, USNM 546140 to 546142) of Mitchell (in press, fig. 3) and spoil (UF 166613).

Description External, and both external and internal (UF 166881) surfaces of valves and bones perforated by numerous, irregularly distributed, circular to elliptical holes of differing sizes (Fig. 1b, c). Specimens free of substrate are individual chambers (Fig. 1g), preserved as thin, smooth, infilled calcite lining to borings preserving small, sub-spherical main chambers with short (but incomplete) necks.

Remarks Specimens of Entobia isp. are apparent as perforations on the surfaces of bones (Fig. 1b) and bivalves (Fig. 1c). Note that the three specimens in which Entobia is recognized only on the external surface of the valve do not 
Fig. 1 Borings in

biomineralized substrates from the Eocene of Seven Rivers,

Jamaica (a-c, f, $\mathbf{g}$ after Donovan et al. 2015, fig. 5a-e,

respectively). a-c, g Entobia isp. a USNM 546142, rib fragment bored with some chambers infilled by white calcite. b USNM 546140, rib fragment showing apertures (right and left of center) and infilled chambers (left). c UF 166940, surface expression of a dense infestation in an ostreid; scale bar represents $50 \mathrm{~mm}$. g UF 166937, calcite infill of a chamber. d-f Small round holes in shells, Oichnus ispp.

d Oichnus paraboloides Bromley, UF 166840, nonpenetrative pit in Anomia. e Oichnus paraboloides Bromley, UF 166844, nonpenetrative pits in an ostreid. f Oichnus simplex Bromley, UF 166847, non-penetrative pit in an ostreid; scale bar represents $2 \mathrm{~mm}$. Scale bars represent $10 \mathrm{~mm}$ unless stated otherwise

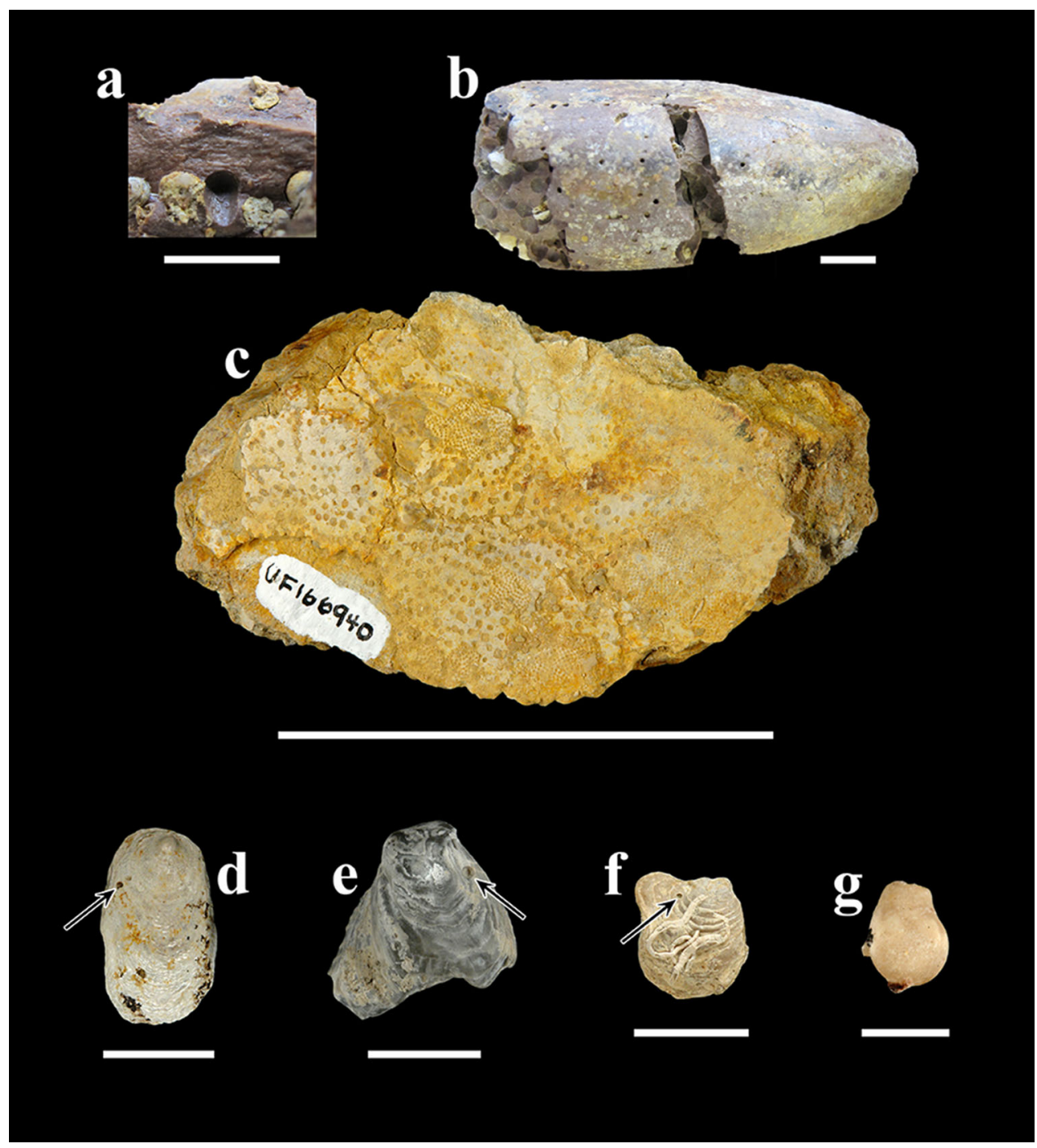

expose the inner surface; these are only seen on broken ribs. UF 166881 is a post-mortem infestation of an ostreid; the other bivalves may have been infested either in vivo or post-mortem.

The individual, infilled chambers liberated from, presumably, crumbling sirenian bones resemble the bivalve boring Gastrochaenolites orbicularis Kelly and Bromley, 1984, which has not been reported from the Antilles hitherto (Donovan and Hensley 2006, table 2). The small size and preservation free of a substrate are unusual. However, our original interpretation of these specimens, that they were produced by juvenile boring bivalves invading a relatively thin shelly, aragonitic substrate which was subsequently lost due to diagenesis, was erroneous. A collection of sirenian bones, mainly ribs and all from unit 18, shown to S.K.D. by Professor D.P. Domning (August 29, 2012), included several specimens that were densely infested by Entobia, preserved both as natural excavations and calcitic casts (Fig. 1a, b). Although unknown from
Seven Rivers, Gastrochaenolites ispp. are a common component of the Cenozoic rock record of Jamaica (see, for example, Donovan et al. 2001; Donovan 2002) and the wider Antilles (Donovan and Hensley 2006; Donovan et al. 2014).

\section{Ichnogenus Oichnus Bromley 1981}

Type ichnospecies Oichnus simplex Bromley 1981, p. 60, by original designation.

Diagnosis (After Donovan and Pickerill 2002, p. 87.) "Small, circular, subcircular, oval or rhomboidal holes or pits of biogenic origin in hard substrates, commonly perpendicular to subperpendicular to substrate surface. Excavation may pass directly through substrate as a penetration, most commonly where the substrate is a thin shell, or may end within the substrate as a shallow to moderately deep depression or short, subcylindrical pit, commonly with a depth:width ratio of $\leq 1$, with or without a central boss." 
Remarks Oichnus ispp. are locally common in diverse shelly substrates of the Cenozoic of Jamaica (see, for example, Pickerill and Donovan 1998; Donovan and Harper 2007; Donovan et al. 2015).

Oichnus simplex Bromley, 1981

Figure 1f

2015 Oichnus simplex Bromley; Donovan et al., p. 370, table 2, fig. 5d.

Material One specimen, UF 166847 (a non-penetrative pit in a valve of an ostreid; Fig. 1f).

Horizon Bed 18-C of Mitchell (in press, fig. 3).

Diagnosis (After Bromley 1981, p. 60.) “Oichnus having a simple cylindrical or subcylindrical form, axis more or less perpendicular to the substrate surface. Where the substrate is not penetrated right through, the distal end is flattened hemispherical."

Description Simple, small $(<0.5 \mathrm{~mm})$, sub-rounded, incomplete hole with axis perpendicular to substrate and no countersunk edge.

Remarks This pit may represent failed predation by a muricid gastropod (see discussion in Pickerill and Donovan 1998, pp. 164-166). As muricids in this fauna are commonly large (see Portell in press), this tiny trace may have been bored by a juvenile. The valve is encrusted by calcareous worm tubes and a bryozoan (Fig. 1f).

Oichnus paraboloides Bromley, 1981

Figure 1d, e

2015 Oichnus paraboloides Bromley; Donovan et al., p. 370 , table 2 .

Material UF 166840 (one non-penetrative pit in a valve of Anomia; Fig. 1d), 166841 (one penetrative borehole and a second incomplete borehole or pit in a valve of Anomia), 166844 (four non-penetrative pits in a valve of ostreid; Fig. 1e) and 166874 (three non-penetrative pits in a valve of Anomia).

Horizon All specimens are from bed 18-C of Mitchell (in press, fig. 3).

Diagnosis (After Bromley 1981, p. 62.) "Oichnus having a spherical paraboloid form, truncated in those cases where the boring penetrates right through the substrate. Where it does not so penetrate, the paraboloid may be deformed by a slightly raised central boss."

Description Small (largest specimen about $1 \mathrm{~mm}$ in diameter), paraboloid, rounded to elliptical, mainly incomplete holes with axis perpendicular to substrate. Outer edges countersunk.

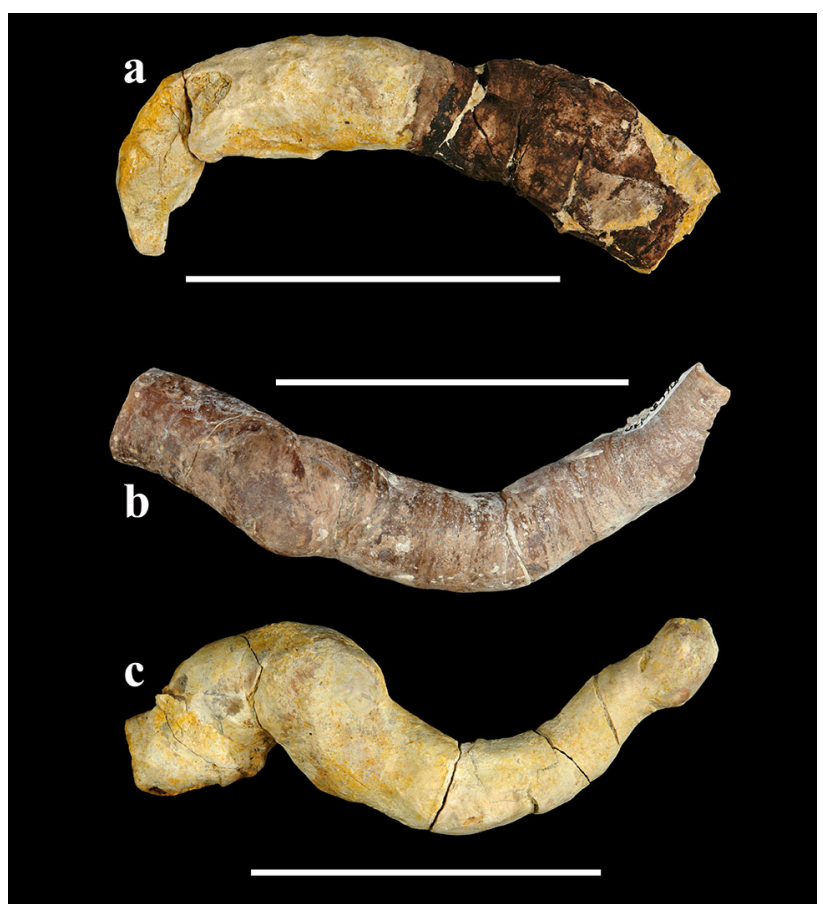

Fig. 2 Infills of bivalve borings, Apectoichnus longissimus (Kelly and Bromley), released from rotted xylic substrates from the Eocene of Seven Rivers, Jamaica. a UF 166582. b UF 166596. c UF 166597 (after Donovan et al. 2015, fig. 5f). Scale bars represent $50 \mathrm{~mm}$

Remarks These pits and the complete borehole may represent examples of failed and successful predation, respectively, by naticid gastropods (see discussion in Pickerill and Donovan 1998, pp. 164-166). Naticids in this fauna are commonly small, as are $O$. paraboloides (see Portell in press). Why so many of these pits should be nonpenetrative in such a thin shell as Anomia is unknown. However, the one borehole is cut by a crack in the valve which links to the second pit in this specimen. It may be that successful predation reduces the chance of preservation by mechanically weakening the valve (Roy et al. 1994; Pickerill et al. 2002, pp. 115-116).

\section{Ichnogenus Apectoichnus Donovan 2018}

Type ichnospecies Teredolites longissimus Kelly and Bromley 1984, pp. 804, 806, text-figs. 9b, 11, by original designation (Donovan 2018, p. 96) from the Aptian (Lower Cretaceous) of Kent, south-east England.

Diagnosis (After Donovan 2018, p. 96.) "Elongate borings, commonly circular in section, smooth-sided, straight or sinuous to contorted and intertwined, with or without a calcareous lining. The boring may change direction and cause a constriction of the tube, but tubes are commonly of more or less constant diameter. May be solitary or gregarious." 
Remarks In Jamaica, Apectoichnus longissimus has been recognized hitherto (as Teredolites longissimus) from the Upper Pliocene turbidites of the Bowden Member including its basal unit, the Bowden shell bed (Pickerill et al. 1996; Donovan et al. 1998). The Bowden Member contains allochthonous examples of A. longissimus, preserved within their host xylic substrates. Apectoichnus longissimus is preserved as short lengths of isolated calcite tubes in the Bowden shell bed. Preservation of A. longissimus elsewhere in the Cenozoic of the Antilles shows a range of taphonomic expressions (for example, Pickerill et al. 2003; Donovan 2014).

Apectoichnus longissimus (Kelly and Bromley 1984)

Figure 2

2015 Teredolites longissimus Kelly and Bromley; Donovan et al., p. 370, table 2, fig. $5 f$.

Material Thirty-three specimens, UF 166565-166566, 166570, 166572-166573, 166577-166582, 166584-166585, 166587-166591, 166593, 166595-166597, 166599-166600, 166602, 166605, 166607, 166719-166724 (Fig. 2). Some of these numbers may refer to two fragments of the same tube that it has not been possible to reconstruct.

Horizon All specimens are from bed 8 of Mitchell (in press, fig. 3).

Diagnosis As for the ichnogenus.

Description Cylindrical, unbranched, gray (when clean) calcite tubes, never complete, but some are of considerable length $(100+\mathrm{mm})$. Tubes more or less tapering gently distally, although some specimens show apparently proximal contractions. Tube section rounded, commonly circular. Tubes sinuous to highly contorted, only straight over short distances. Distal termination either conical or bulbous. Geniculations of tubes uncommonly swollen. Tubes commonly infilled with sedimentary rock, rarely with woody inclusions; although sedimentary rock has dropped out of some specimens, the internal walls are invariably masked by adhering mudrock.

Growth lines on outside of tube perpendicular to long axis, formed by a cone-in-cone arrangement of successive layers. Walls up to $40 \%$ of tube diameter proximally, the concentric arrangement of layers apparent on broken ends. Walls commonly thicken proximally, although the base of some specimens may be particularly thick.

Remarks These specimens are not immediately apparent as Apectoichnus. None of them is preserved in a woody substrate, although UF 166582 has, in part, a dark carbonaceous external film that is suggestive of a xylic origin and other specimens include carbonized woody inclusions (including UF 166570, 166593). They are interpreted as $A$. longissimus tubes that were released into the sediment after their enclosing woody substrates rotted away. Particularly, some of the convoluted tubes are reminiscent of the type series (Kelly and Bromley 1984, text-fig. 11) and other, closely packed associations of this species (see, for example, Savrda and Smith 1996, fig. 1; Savrda et al. 2005, fig. 5).

\section{Discussion}

The small suite of trace fossils described above provides limited palaeoecological information about the Seven Rivers site. Because of its pseudoplanktonic lifestyle, A. longissimus is an archetypal facies-crossing trace fossil. However, it is the commonest trace fossil in this assemblage, which may have been a function of Jamaica's proximity to the Yucatán Peninsula of Mexico and its shoreline at this time (Domning et al. 1997; Donovan et al. 2007). As the Caribbean Plate ground its way east, Jamaica became completely submerged (Draper 1987) and far distant from any landmass. It was only after renewed tectonic activity had raised the Jamaican landmass above sea level that Apectoichnus was again found in the Jamaican rock record (Pickerill et al. 1996; Donovan et al. 1998). Thus, a nearby coastline is apparently a decisive factor determining the presence of Apectoichnus in the rock record of Jamaica. In contrast, Entobia and Gastrochaenolites Leymerie, 1842 are typical ichnofossils in a wide range of shallowwater, open-marine settings.

Acknowledgements Of the many colleagues who contributed to our fieldwork at Seven Rivers, in the present context we emphasize the zeal of the late H.L. (Hal) Dixon for collecting invertebrate body and trace fossils. We offer special thanks to Professor Simon F. Mitchell (University of the West Indies, Mona) for providing a pre-print of his paper. The supportive reviews of Drs John W.M. Jagt (Natuurhistorisch Museum Maastricht, The Netherlands) and Donovan J. Blissett (University of the West Indies, Mona) are gratefully acknowledged.

\section{References}

Bateson, J.H. (undated). Montego Bay. Jamaica, 1:50,000, Geological Sheet 3 (provisional). Government of Jamaica, Kingston.

Berg, D. E. (1969). Charactosuchus kugleri, eine neue Krokodilart aus dem Eozän von Jamaica. Eclogae Geologicae Helvetiae, 62, 731-735.

Blissett, D. J., \& Pickerill, R. K. (2003). Soft-sediment ichnotaxa from the Eocene-Miocene White Limestone Group, Jamaica, West Indies. Scripta Geologica, 127, 341-378.

Blissett, D. J., \& Pickerill, R. K. (2004). Observations on macroborings from the White Limestone Group of Jamaica. Cainozoic Research, 3(for 2003), 167-187. 
Blissett, D. J., \& Pickerill, R. K. (2007). Systematic ichnology of microborings from the Cenozoic White Limestone Group, Jamaica, West Indies. Scripta Geologica, 134, 77-108.

Blissett, D. J., Pickerill, R. K., \& Rigby, J. K. (2007). A new species of boring sponge from the White Limestone Group, Jamaica. Caribbean Journal of Science, 42, 246-250.

Bromley, R.G. (1970). Borings as trace fossils and Entobia cretacea Portlock, as an example. In T.P. Crimes, \& J C. Harper (Eds), Trace fossils. Geological Journal Special Issue (vol. 3, pp. 49-90).

Bromley, R. G. (1981). Concepts in ichnotaxonomy illustrated by small round holes in shells. Acta Geológica Hispánica, 16, $55-64$.

Bromley, R.G. (2004). A stratigraphy of marine bioerosion. In D. McIlroy (Ed.), The application of ichnology to palaeoenvironmental and stratigraphic analysis. Geological Society, London, Special Publication (vol. 228, pp. 455-479).

Bromley, R. G., \& d'Alessandro, A. (1984). The ichnogenus Entobia from the Miocene, Pliocene and Pleistocene of southern Italy. Rivista Italiana di Paleontologia e Stratigrafia, 90, 227-296.

Bronn, H. G. (1837-1838). Lethaea geognostica. 2. Die Kreide und Molassen. Stuttgart: Schweizerbart (pp. 545-1350). [Not seen].

Dall, W. H. (1898). Contributions to the Tertiary fauna of Florida with especial reference to the Miocene Silex-beds of Tampa and the Pliocene beds of the Caloosahatchie River including in many cases a complete revision of the generic groups treated of and their American Tertiary species. Part IV. Prionodesmacea (Nucula to Julia) and Teleodesmacea (Teredo to Ervilia). Transactions of the Wagner Free Institute of Science of Philadelphia, 3, 571-947.

Domning, D. P. (2001). The earliest known fully quadrupedal sirenian. Nature, 413, 625-627.

Domning, D. P., Emry, R. J., Portell, R. W., Donovan, S. K., \& Schindler, K. S. (1997). Oldest West Indian land mammal: rhinoceratoid ungulate from the Eocene of Jamaica. Journal of Vertebrate Paleontology, 17, 638-641.

Domning, D. P., \& Portell, R. W. (Eds.) (in press). The Eocene fossil site of Seven Rivers, Jamaica: Geology, paleontology, and evolutionary and biogeographic implications. Heidelberg: Springer.

Donovan, S. K. (2002). A new ichnospecies of Gastrochaenolites Leymerie from the Pleistocene Port Morant Formation of southeast Jamaica and the taphonomy of calcareous linings in clavate borings. Ichnos, 9, 61-66.

Donovan, S. K. (2004). Editor's preface. In S. K. Donovan (Ed.), The Mid-Cainozoic White Limestone Group of Jamaica. Cainozoic Research (for 2003), 3-4.

Donovan, S. K. (2014). The trace fossil Teredolites longissimus Kelly and Bromley, 1984, from the Eocene of Curaçao. Caribbean Journal of Science, 47(for 2013), 181-185.

Donovan, S. K. (2018). A new ichnogenus for Teredolites longissimus Kelly and Bromley. Swiss Journal of Palaeontology, 137, 95-98.

Donovan, S. K., \& Blissett, D. J. (1998). Palaeoecology of the giant Eocene gastropod Campanile. Eclogae Geologicae Helvetiae, 91, 453-456.

Donovan, S. K., Blissett, D. J., \& Currant, A. P. (2001). Trace fossils of the Lower Pleistocene Manchioneal Formation of eastern Jamaica. Caribbean Journal of Science, 37, 292-295.

Donovan, S. K., Blissett, D. J., \& Pickerill, R. K. (2015). Jamaican Cenozoic ichnology: Review and prospectus. Geological Journal, 50, 364-382.

Donovan, S. K., Domning, D. P., Garcia, F. A., \& Dixon, H. L. (1990). A bone bed from the Eocene of Jamaica. Journal of Paleontology, 64, 660-662.
Donovan, S. K., \& Ewin, T. A. M. (2018). Substrate is a poor ichnotaxobase: a new demonstration. Swiss Journal of Palaeontology, 137, 103-107.

Donovan, S. K., \& Harper, D. A. T. (2007). Rare borings in Pleistocene brachiopods from Jamaica and Barbados. Caribbean Journal of Science, 43, 59-64.

Donovan, S. K., Harper, D. A. T., Portell, R. W., \& Renema, W. (2014). Neoichnology and implications for stratigraphy of reworked Upper Oligocene oysters, Antigua, West Indies. Proceedings of the Geologists' Association, 125, 99-106.

Donovan, S. K., \& Hensley, C. (2006). Gastrochaenolites Leymerie in the Cenozoic of the Antillean region. Ichnos, 13, 11-19.

Donovan, S.K., Paul, C.R.C., \& Littlewood, D.T.J. (1998). A brief review of the benthic Mollusca of the Bowden shell bed, southeast Jamaica. In S.K. Donovan (Ed.), The Mid-Cainozoic White Limestone Group of Jamaica. Contributions to Tertiary and Quaternary Geology (vol. 35, pp. 85-93).

Donovan, S. K., \& Pickerill, R. K. (2002). Pattern versus process or informative versus uninformative ichnotaxonomy: Reply to Todd and Palmer. Ichnos, 9, 85-87.

Donovan, S. K., Portell, R. W., \& Domning, D. P. (2007). Contrasting patterns and mechanisms of extinction during the EoceneOligocene transition in Jamaica. In W. Renema (Ed.), Biogeography, time and place: Distributions, barriers and islands (pp. 247-273). Dordrecht: Springer.

Donovan, S. K., Renema, W., \& Pickerill, R. K. (2005). The ichnofossil Scolicia prisca de Quatrefages from the Paleogene of eastern Jamaica and fossil echinoids of the Richmond Formation. Caribbean Journal of Science, 41, 876-881.

Donovan, S. K., \& Stemann, T. A. (2007). Where have all the sponges gone? The significance of spicules from the Upper Pliocene Hopegate Formation of Jamaica. Caribbean Journal of Science, 42(for 2006), 239-243.

Draper, G. (1987). A revised tectonic model for the evolution of Jamaica. In R. Ahmad (Ed.), Proceedings of a workshop on the status of Jamaican geology. Journal of the Geological Society of Jamaica, Special Issue 10, (151-169).

Häntzschel, W. (1962). Trace fossils and Problematica. In R. C. Moore (Ed.), Treatise on Invertebrate Paleontology, Part W, Miscellanea (pp. W177-W245). New York: Geological Society of America and University of Kansas.

Höpner, S., \& Bertling, M. (2017). Holes in bones: Ichnotaxonomy of bone borings. Ichnos, 24, 259-282.

Kelly, S. R. A., \& Bromley, R. G. (1984). Ichnological nomenclature of clavate borings. Palaeontology, 27, 793-807.

Leymerie, A. (1842). Suite de mémoire sur le terrain Crétacé du département de l'Aube. Mémoires de la Société Géologique de France, 5, 1-34.

Mitchell, S.F. (in press). Geology of the Seven Rivers sea cow site. In D.P. Domning, \& R.W. Portell (Eds.), The Eocene fossil site of Seven Rivers, Jamaica: Geology, paleontology, and evolutionary and biogeographic implications. Heidelberg: Springer.

Pickerill, R. K., \& Donovan, S. K. (1991). Observations on the ichnology of the Richmond Formation of eastern Jamaica. Journal of the Geological Society of Jamaica, 28, 19-35.

Pickerill, R.K., \& Donovan, S.K. (1998). Ichnology of the Pliocene Bowden shell bed, southeast Jamaica. In S.K. Donovan (Ed.), The Mid-Cainozoic White Limestone Group of Jamaica. Contributions to Tertiary and Quaternary Geology (vol. 35, pp. 161-175).

Pickerill, R. K., Donovan, S. K., \& Dixon, H. L. (1992). The Richmond Formation of eastern Jamaica revisited-Further ichnological observations. Caribbean Journal of Science, 28, 89-98.

Pickerill, R. K., Donovan, S. K., Doyle, E. N., \& Dixon, H. L. (1993). Ichnology of the Paleogene Richmond Formation of eastern Jamaica-The final chapter? Atlantic Geology, 29, 61-67. 
Pickerill, R. K., Donovan, S. K., \& Portell, R. W. (2002). Bioerosional trace fossils from the Miocene of Carriacou, Lesser Antilles. Caribbean Journal of Science, 38, 106-117.

Pickerill, R. K., Donovan, S. K., \& Portell, R. W. (2003). Teredolites longissimus Kelly and Bromley from the Miocene Grand Bay Formation of Carriacou, the Grenadines, Lesser Antilles. Scripta Geologica, 125, 1-9.

Pickerill, R. K., Keighley, D. G., \& Donovan, S. K. (1996). Ichnology of the Pliocene Bowden Formation of southeastern Jamaica. Caribbean Journal of Science, 32, 221-232.

Pickerill, R. K., \& Mitchell, S. F. (1999). The graphoglyptid trace fossil Spiroraphe involuta (de Stefani, 1895) from eastern Jamaica. Journal of the Geological Society of Jamaica, 33, $13-16$.

Portell, R.W. (in press). Mollusca. In D.P. Domning, \& R.W. Portell (Eds.), The Eocene fossil site of Seven Rivers, Jamaica: Geology, paleontology, and evolutionary and biogeographic implications. Heidelberg: Springer.

Portell, R. W., Donovan, S. K., \& Domning, D. P. (2001). Early Tertiary vertebrate fossils from Seven Rivers, parish of St. James, Jamaica, and their biogeographic implications. In C.
A. Woods \& F. E. Sergile (Eds.), Biogeography of the West Indies: Patterns and perspectives (2nd ed., pp. 191-200). Boca Raton: CRC Press.

Portlock, J.E. (1843). Report on the geology of the county of Londonderry, and parts of Tyrone and Fermangh, and c. HMSO, Dublin (p. xxxi + 784).

Robinson, E. (1969). Stratigraphy and age of the Dump Limestone lenticle, central Jamaica. Eclogae Geologicae Helvetiae, 62, 737-744.

Roy, K., Miller, D. J., \& Labarbera, M. (1994). Taphonomic bias in analyses of gastropod drill holes on bivalve shell strength. Palaios, 9, 413-421.

Savrda, C. E., Counts, J., McCormick, O., Urash, R., \& Williams, J. (2005). Log-grounds and Teredolites in transgressive deposits, Eocene Tallahatta Formation (southern Alabama, USA). Ichnos, 12, 47-57.

Savrda, C. E., \& Smith, M. W. (1996). Behavioral implications of branching and tube lining in Teredolites. Ichnos, 4, 191-198.

Wright, R. M., \& Robinson, E. (Eds.). (1993). Biostratigraphy of Jamaica (Vol. 182, p. xi+492). Boulder: Geological Society of America Memoir. 